\title{
INFLUENCE OF MANURE WITH ACTIVATORS OF ORGANIC MATTER ON PHYSICAL PROPERTIES OF SOIL
}

\author{
Petr Novak $^{1}$, Petr Sarec ${ }^{1}$, Oldrich Latal ${ }^{2}$, Martin Brtnicky ${ }^{3}$, Jiri Masek ${ }^{1}$ \\ ${ }^{1}$ Czech University of Life Sciences Prague, Czech Republic; \\ ${ }^{2}$ Agrovyzkum Rapotin S.R.O., Czech Republic; ${ }^{3}$ Mendel University in Brno, Czech Republic \\ novakpetr@tf.czu.cz, oldrich.latal@vuchs.cz,masekj@tf.czu.cz
}

\begin{abstract}
Soil decarbonisation is a long-term problem in almost all agriculturally important areas and, of course, in the Czech Republic also. This is due to decrease in livestock production and due to associated decrease in organic fertilizer production. Application of manure is one of the best ways to change this condition. Manure can be added by biological activators of organic matter. The main aim of the paper is to authenticate the benefit of modified farmyard manure and of substances for soil amendment on the improvement of physical, physicalchemical and biological soil properties, on organic matter fixation, on improvement of water infiltration and retention, on reduction of soil erosion susceptibility, and on reduction of soil tillage energy demand. In this respect, multi-annual field experiments have been established at locality Lázně Bělohrad in the North of Bohemia. Semi-operational experiment consists of six variants and it was established in 2014. As the biological transformation's activator, PRP sol agent has been used. In order to verify the effect, soil infiltration abilities have been measured using a ring infiltrometer with a diameter of 0.15 meters. Cone index has been another measured item provided by the registration penetrometer. Soil physical properties have been evaluated employing Kopecky's cylinders and subsequently analysed in the laboratories of the CULS Prague. Improvements have been observed in decrease in the bulk density, increase in porosity, decrease in the cone index and increase in saturated hydraulic conductivity.
\end{abstract}

Keywords: cone index; infiltration into soil, manure.

\section{Introduction}

The exchange of nutrients, energy and carbon between the soil organic matter, soil environment, aquatic systems and the atmosphere is important for agricultural productivity, water quality and climate. Long-standing theory suggests that soil organic matter is composed of inherently stable and chemically unique compounds [1]. In the Czech Republic, as well as in many other localities, there is a problem with the decrease in the amount of organic carbon in the soil [2]. In the last few decades there has been a decline in livestock numbers, along with the number of organic fertilizers applied [3]. Thanks to the change in the subsidy policy, composting and other measures, this situation is gradually changing. Organic matter is applied to the soil as manure, compost and waste from biogas plants. Decomposition of organic matter in soils with low levels of carbon may constitute a problem [4]. This status can be improved with the use of activators of organic matter. Effect of the use of activators on soil properties is a relatively unexplored phenomenon. Impact can be mainly expected on the physical and chemical properties of soil.

The current pressure and need of increasing the soil structure, its conservation and increase of soil fertility lead to increased research efforts, and various soil biological activators were developed. According to this effort, a field experimental research was addressed [5]. Kroulík et al. [6] suggested a beneficial effect of incorporation of organic matter on the physical properties of soil, on water infiltration into the soil and on partial elimination of the consequences of soil compaction after the tracks. It can be also assumed that changes in soil properties will be reflected in the long term rather than immediately after application.

In the previous research, the work has been unable to clearly demonstrate the beneficial effect of activators of organic matter on parameters of water infiltration into the soil [2]. This is probably due to the short duration of the experiment. Another possibility is the influence of soil parameters of the selected plot for the measurement. Especially light soil infiltration parameters are always strong, even without further intervention. In general, changes in the soil environment are long-term and therefore their investigation must last for many years and cannot be generalized for all soil conditions.

The aim of the study was to assess and evaluate the effect of the activator on the spatial variability of soil environment. 


\section{Materials and methods}

Semi operational field experiment was established to demonstrate the influence of the activators of organic matter. The establishment of the experiment occurred in 2014 after wheat harvest. The experiment has been designed to 6 basic variants. The experimental field is located in Lázně Bělohrad

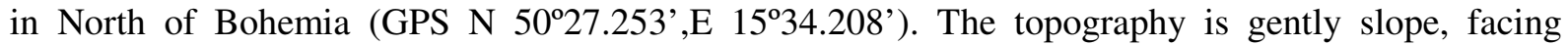
southwest. Altitude is $360 \mathrm{~m}$. Soil type on the location Lázně Bělohrad is modal luvisol. The content of particles $<0.01 \mathrm{~mm}$ : $30 \%$ weight (depth $0-0.3 \mathrm{~m}$ ). The experimental plot was divided into individual variants, where fertilizer application was carried out according to a plan, and autumn ploughing to a depth of $0.25 \mathrm{~m}$ was implemented. The fertilizer used was manure (breeding cattle), NPK 15-15-15 (Lovofert). The soil activator used was PRP Sol (PRP Technologies). PRP Sol is formed by a matrix of calcium and magnesium carbonate, and mineral elements. Activator of the biological transformation of manure was PRP Fix (PRP Technologies). The variants differed by the fertilizers used. Dosage of manure was 50 t.ha ${ }^{-1}$, of PRP Sol $200 \mathrm{~kg} \cdot \mathrm{ha}^{-1}$, and of NPK $200200 \mathrm{~kg} \cdot \mathrm{ha}^{-1}$. PRP Fix (PRP Technologies) activator was added directly into the bedding. PRP Fix is a granular mixture of mineral salts and carbonates. Both activators cannot be understood as fertilizers. They should improve conditions for the transformation of organic matter. Fertilization of individual variants is shown in Table 1.

\section{Fertilization of individual variants of field experiment}

Table 1

\begin{tabular}{|l|l|}
\hline Variant & Fertilization \\
\hline 1 & Manure + Fix + Sol \\
\hline 2 & Manure + Fix \\
\hline 3 & Manure + Sol \\
\hline 4 & Manure \\
\hline 5 & NPK + Sol \\
\hline 6 & NPK - control \\
\hline
\end{tabular}

The soil was prepared by a seedbed combinator after ploughing. Winter wheat was sown on all variants. In April 2018 the measurements were taken (after BBCH 35). There were three basic methods of measurements. Soil infiltration abilities have been measured using a ring infiltrometer with a diameter of $0.15 \mathrm{~m}$. The method used was a simplified falling-head [7] Bagarello et al. [8] that converts infiltration into saturated hydraulic conductivity. Infiltrometer was poured into a known amount of water and the soak time was measured (20 repetitions on each variant).

Cone index has been another measured item provided by the registration penetrometer. PN-10 penetrometer with a cone having an angle $30^{\circ}$ (area of $100 \mathrm{~mm}^{2}$ ) was used. The penetrometer was developed at CULS in Prague. Soil physical properties have been evaluated employing Kopecky's cylinders with volume $100 \mathrm{~cm}^{3}$ and subsequently analysed in the laboratories of the CULS Prague. Moisture was measured by Theta Probe (Delta Devices). Data were processed by the programmes MS Excel (Microsoft Corp., USA) and Statistica 12 (Statsoft Inc., USA). The paper contains data from the season 2018.

\section{Results and discussion}

Table 2 shows the values of physical properties of the soil in three depths. These values confirm the initial hypothesis, i.e. the apparent beneficial effects of manure in the soil, but also improved effect using activators of organic matter. From these results a decrease of the density of the soil in relation to the application of manure can be discerned. The results suggest beneficial effect of the activators in terms of incorporation of organic matter. The measurement trend was recorded for soil porosity and bulk density during the season 2018. Differences are relatively small (below statistical significance). But the physical properties of the soil are changing typically slow.

Figure 1 is a graph of saturated hydraulic conductivity for all variants (season 2018). There are visible differences among each of the variants. These are relatively low. This is probably due to the short exposure of activators and applied manure. However, the measurement trend clearly demonstrates the beneficial effect of activators on the hydraulic properties of the soil. The lowest 
values were reported by variant 6 without application. The largest variance (variant 4) is probably due to the poorer decomposition of the applied manure.

Table 2

Bulk density at Lázně Bělohrad in April, 2018

\begin{tabular}{|c|c|c|c|c|c|c|}
\hline Variant & $\mathbf{1}$ & $\mathbf{2}$ & $\mathbf{3}$ & $\mathbf{4}$ & $\mathbf{5}$ & $\mathbf{6}$ \\
\hline Depth, m & \multicolumn{7}{|c|}{ Bulk density, $\mathbf{g}^{-\mathbf{c m}^{-3}}$} \\
\hline $\mathbf{0 . 0 5 - 0 . 1}$ & 1.37 & 1.43 & 1.43 & 1.39 & 1.52 & 1.52 \\
\hline $\mathbf{0 . 1 - 0 . 1 5}$ & 1.48 & 1.49 & 1.49 & 1.52 & 1.49 & 1.55 \\
\hline $\mathbf{0 . 1 5 - 0 . 2}$ & 1.52 & 1.50 & 1.48 & 1.46 & 1.58 & 1.60 \\
\hline Depth, m & 42 & 41 & 42 & 43 & 40 & 39 \\
\hline $\mathbf{0 . 0 5 - 0 . 1}$ & 42 & 40 & 41 & 36 & 36 \\
\hline $\mathbf{0 . 1 - 0 . 1 5}$ & 41 & 39 & 40 & 37 & 37 & 35 \\
\hline $\mathbf{0 . 1 5 - 0 . 2}$ & 41 & 38 & &
\end{tabular}

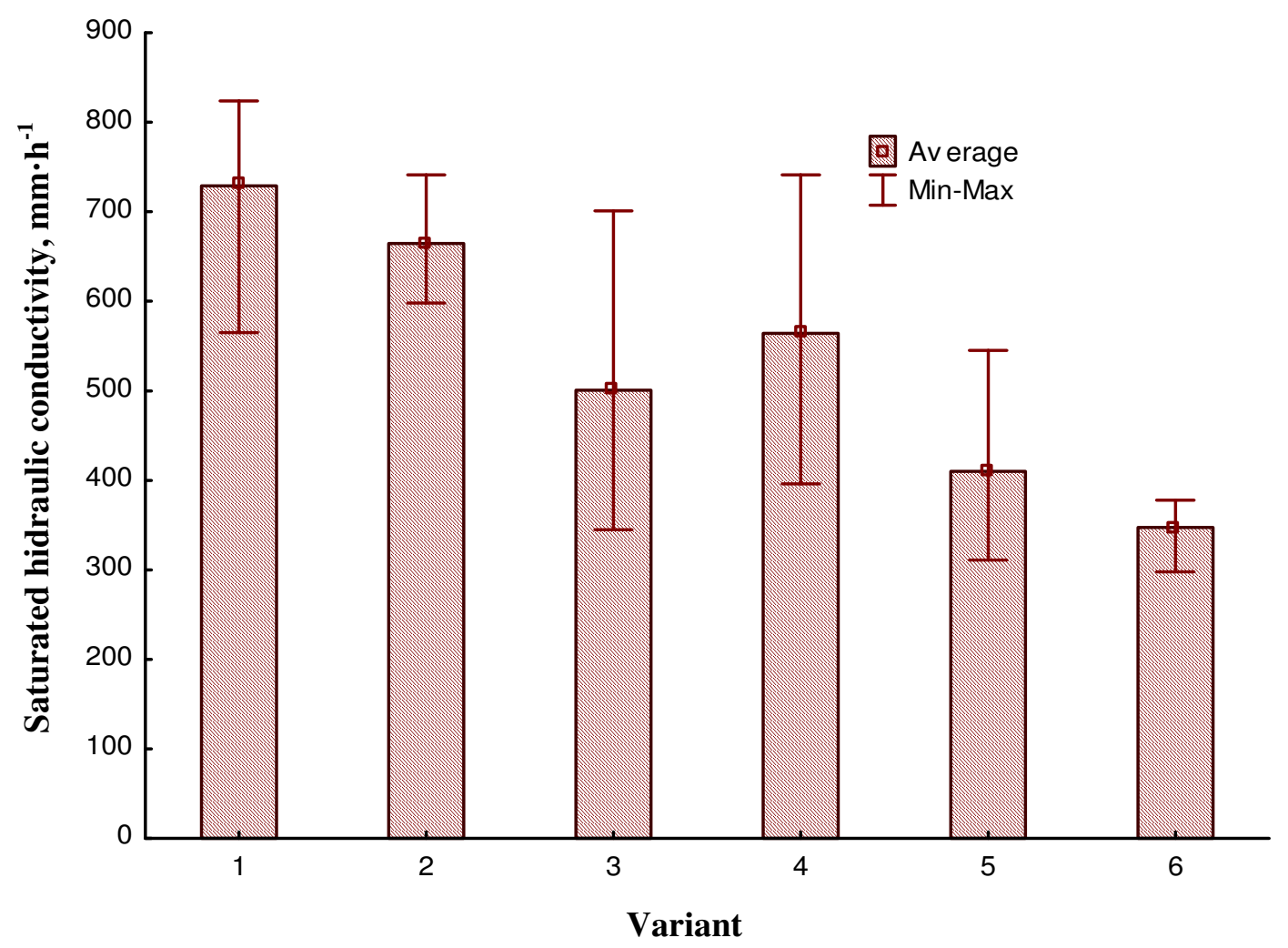

Fig. 1. Saturated hydraulic conductivity in season 2018

Figure 2 is a graph of the cone index for all variants. The graph shows a gradual increase in the values with the depth of measurement. The values of the cone index generally have a high dispersion. From the measurement of the cone index it is not possible to draw a clear conclusion. Differences are below statistical significance. The cone index measurement is also significantly affected by the soil moisture.

The measurements carried out during the 2018 season confirmed the beneficial effects of the activators, in particular on the hydraulic and physical properties of the soil. Urbaničová et al. [5] found that the evaluation of recorded values has revealed the effect of treatment by PRP-SOL activators on the soil infiltration ability, and therefore it results in increases of infiltration of precipitation as well. Overall increase of infiltration was recorded at the value $2 \mathrm{~mm} \cdot \mathrm{h}^{-1}$. It can be concluded that application of soil activators may increase the soil conditions, and therefore not only conserve the soil fertility, but even increase it from the long term perspective. This is consistent with the assertions of other authors [2;3]. Lestingi et al. [9] also mention the risk for bacterial activity caused by agricultural activities. In their previous study [10] they also highlighted the impact on the yield. 


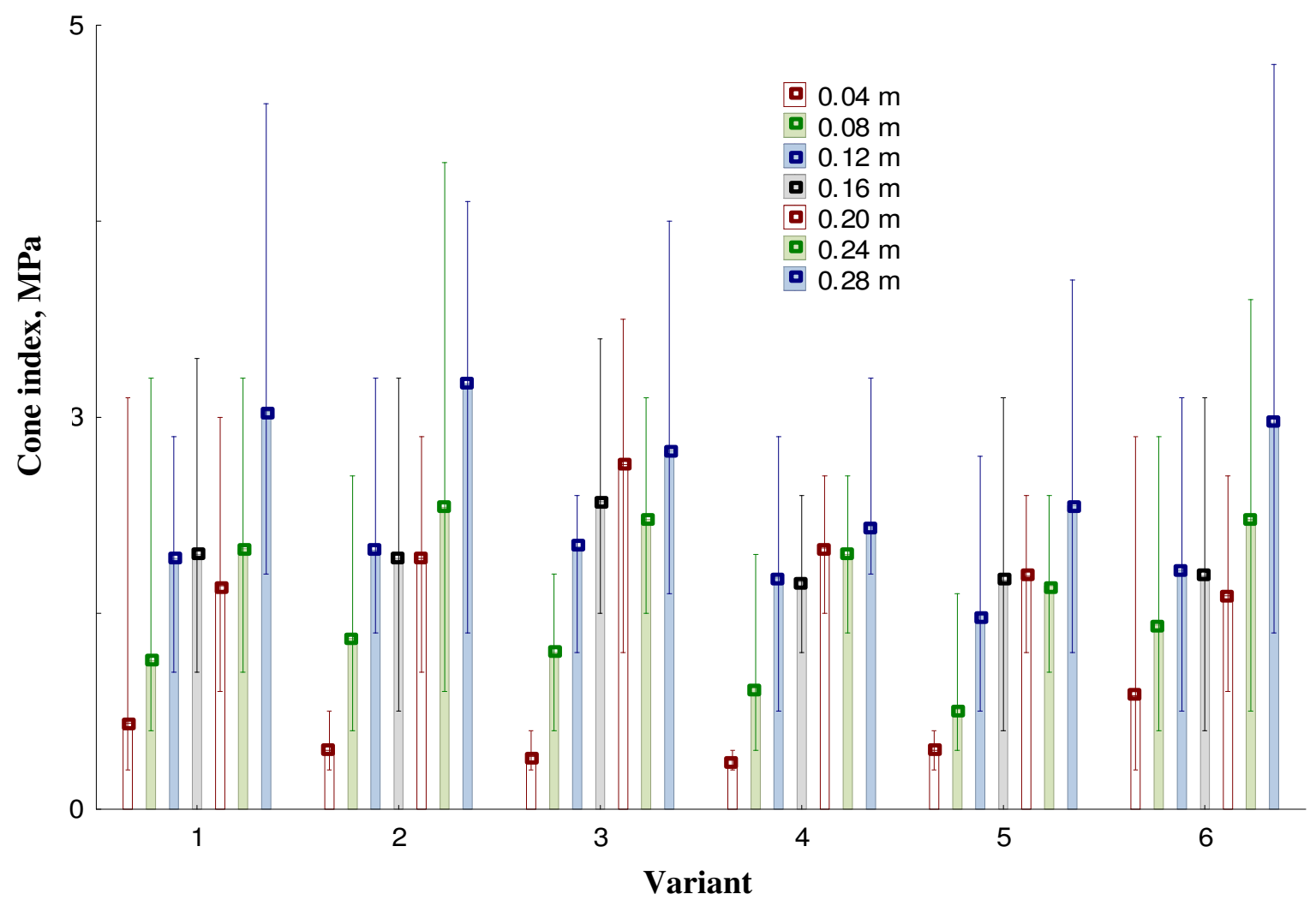

Fig. 2. Cone index in season 2018

\section{Conclusions}

1. During the measurement of the physical properties of soil, favourable effect on the bulk density and porosity of the soil could be observed.

2. However, this was not confirmed by the cone index values measured.

3. Very good are observable effects on the soil hydraulic properties.

4. Again, the necessity for long-term examination of the effects of activators of organic matter should be emphasized.

5. The research needs to be validated in more locations in order to eliminate the influence of the local environment.

\section{Acknowledgements}

This work was supported by the Research Project of the Technology Agency of the Czech Republic No. TH02030169.

\section{References}

[1] LehmannJ., Kleber M. The contentious nature of soil organic matter. Nature, vol. 528.7580, 2015, $60 \mathrm{p}$.

[2] Šařec P., Novák P. Influence of manure and activators of organic matter biological transformation on selected soil physical properties of Modal Luvisol. Agronomy Research, vol. 15(2), 2017, pp. 565-575.

[3] Sařec P., Novák P. Influence of biological transformation of organic matter on improvement of water infiltration ability of modal luvisol. . Proceedings of International conference "6th International Conference on Trends in Agricultural Engineering (TAE)", CULS in Prague, 2016, pp. 627-632.

[4] Ames R. N., Reid C. P. P., Ingham E. R. Rhisosphere bacterial population responses to root colonization by a vesicular-arbuscular mycorrhizal fungus. New Phytologist, vol. 96, 1984, pp. 555-563. 
[5] Urbanovičová O., Mráz M., Findura P., Krištof K., Križan M., Jobbágy J. The effect of soil conditioner on the spatial variability of soil environment. Agronomy Research, vol. 16(5), 2018, pp. 2197-2210.

[6] Kroulík M., Kvíz Z., Kumhála F., Hůla J., Loch T. Procedures of soil farming allowing reduction of compaction. Precision Agriculture, vol. 12, 2011, pp. 317-333.

[7] Bagarello V., Iovino M., Elrick D. A Simplified Falling-Head Technique for Rapid Determination of Field-Saturated Hydraulic Conductivity. Soil Science Society of America Journal, vol. 68, 2004, pp. 66-73.

[8] Bagarello V., Elrick D. E., Iovino M., Sgroi A. A laboratory analysis of falling head infiltration procedures for estimating the hydraulic conductivity of soils. Geoderma, vol. 135, 2006, pp. 322-334.

[9] Lestingi A., Bovera F., Piccolo V., Convertini G., Montemurro F. Effects of compost organic amendments on chemical composition and in vitro digestibility of alfalfa (Medicago sativa L.). Ital Journal Animal Science, vol. 8, 2009, pp. 201-209.

[10] Lestingi A., De Giorgio D., Montemurro F., Convertini G., Laudadio V. Effects of bio-activators on yield and quality composition of triticale forage as an animal food resource. Journal of Food, Agriculture and Environment, vol. 5, 2007, pp.164-171. 